\title{
Método de pregar português
}

Gilson José dos Santos

Doutor em Letras: Estudos Literários / UFMG

\begin{abstract}
RESUMO
Este artigo aborda, em linhas gerais, o esquema retórico que parece ter disciplinado a elaboração de discursos religiosos em Portugal e na América Portuguesa na primeira fase do Barroco: o método português de pregar. Algumas características desse método serão listadas e exemplificadas com base nos sermões de Antônio de Sá (1620-1678), autor considerado um dos modelos da parenética barroca praticada na América Portuguesa.
\end{abstract}

\section{PALAVRAS-CHAVE}

Literatura brasileira, prosa barroca

A enorme importância atribuída à oratória sagrada, na vida portuguesa, desde cedo se fez sentir na necessidade de compendiar e difundir as regras que, numa época em que tudo se pautava por elas, pudessem guiar o trabalho do grande número de pregadores que, diariamente, subiam aos púlpitos de Lisboa e das principais cidades e vilas do Reino. ${ }^{1}$

A necessidade diária de compor prédicas - sempre pautadas por normas que se transmitiam por compêndios e na leitura dos melhores autores - teria, de forma natural, conduzido os pregadores portugueses a desenvolver um método de pregar característico. No século XVII, esse método - que viria a denominar-se "método de pregar português" - já estaria, em linhas gerais, consolidado, e seus traços distintivos poderiam ser apreendidos diretamente na obra de oradores modelares, sobretudo na de Antônio Vieira. ${ }^{2}$

Eis como Aníbal Pinto de Castro define esse método:

A teoria expressa no Sermão da Sexagésima contém, nas suas censuras e nas suas afirmações, a base do "método" que há-de vir a chamar-se "português". Apresenta e aplica o mesmo esquema de desenvolvimento e a mesma

\footnotetext{
${ }^{1}$ CASTRO. Retórica e teorização literária em Portugal, p. 84-85.

${ }^{2}$ CASTRO. Retórica e teorização literária em Portugal: do Humanismo ao Neoclassicismo, p. 86.
} 
estrutura das diversas partes que nele hão-de ser consideradas essenciais: o uso do tema latino, o exórdio, a definição da matéria e a sua divisão, a confirmação baseada em provas, exemplos ou textos e, finalmente, a peroração. $^{3}$

Segundo Castro, o Sermão da Sexagésima, além da prática oratória ali plasmada, apresentaria os pressupostos teóricos que amparam seu edifício retórico. Os traços distintivos do método seriam: "o mesmo esquema de desenvolvimento e a mesma estrutura das diversas partes"; "tema latino", retirado da Bíblia; "conceito predicável”, usado como procedimento argumentativo e método de construção de um discurso; e, ainda, a conjunção entre "unidade" e "diversidade", própria da estética barroca. De fato, o próprio Vieira revela que o Sermão da Sexagésima seria a súmula de uma Retórica Sagrada que ideava escrever; e dessa intenção é testemunho esta citação:

Se chegar a receber a última forma um Livro, que tenho ideado com título de Pregador, e Ouvinte Cristão, nele verás as regras, não sei se da arte, se do génio, que me guiaram por este novo caminho. Entretanto se quiseres saber as causas, por que me apartei do mais seguido, e ordinário, no sermão Semen est verbum Dei, as acharás: o qual por isso se põe em primeiro lugar, como prólogo dos demais. ${ }^{4}$

Mas é de se supor que Vieira nunca tenha passado dessa fase - velho e doente, consagrava seu tempo à preparação dos textos de seus sermões para publicação. ${ }^{5}$ Parece consenso, hoje em dia, que Vieira não escreveu uma obra intitulada Pregador e Ouvinte Cristão nem qualquer outro tratado de retórica. ${ }^{6}$

A teoria retórica praticada por Vieira e seus contemporâneos, como, por exemplo, Antônio de Sá, fundava-se na leitura de oradores e teóricos clássicos, sobretudo Aristóteles, Cícero e Quintiliano. A essas leituras somavam-se a leitura de compêndios preparados por membros da Companhia de Jesus e a observação direta das pregações de padres da igreja. ${ }^{7}$ Naturalmente, o conhecimento retórico dos pregadores jesuítas não provinha apenas dessas leituras; além delas, haveria outras, como, por exemplo, a leitura de textos filosóficos e literários de autores latinos e gregos. A formação literária dos jesuítas, dirigida pelos preceitos do Ratio Studiorum, de 1599, poderia sugerir-lhes vários motivos e recursos expressivos oportunos à pregação. Assim, parece certo que Vieira e seus companheiros de ordem religiosa

\footnotetext{
${ }^{3}$ CASTRO. Retórica e teorização literária em Portugal: do Humanismo ao Neoclassicismo, p. 107.

${ }^{4}$ VIEIRA. Sermões: I, p. 6.

${ }^{5}$ CASTRO. Retórica e teorização literária em Portugal: do Humanismo ao Neoclassicismo, p. 90-91.

${ }^{6} \mathrm{Cf}$. MENDES. A oratória barroca de Vieira, p. 178.

${ }^{7}$ Cf. CASTRO. Retórica e teorização literária em Portugal: do Humanismo ao Neoclassicismo, p. 94.
} 
- nesse caso, Antônio de Sá - seguem a prática retórica que, a partir do século XVI, estabeleceu-se na confluência da herança medieval com a refundição renascentista da herança clássica. ${ }^{8} \mathrm{E}$ tais contribuições teriam sido organizadas e dado origem a uma maneira particular de compor prédicas - o "método de pregar" português.

\section{As BASES DO MÉTODO DE PREGAR PORTUGUÊS}

As obras dessa época (séculos XVI e XVII), consagradas à Retórica Eclesiástica, que contêm o corpo doutrinário em que se codifica esse método estão perdidas, na sua maior parte, ou são de identificação bastante difícil, por vezes, impossível; não faltam, porém, nos registros bibliográficos, sobretudo na Biblioteca Lusitana, referências a essas obras. E muitas outras, não registradas, dormem manuscritas em bibliotecas portuguesas. ${ }^{9}$ No quadro geral dessas obras, uma desperta interesse especial:

Resta-nos, porém, desta época um texto que reputamos da maior importância para o estudo do método português e, por conseguinte, da produção cancionatória nele baseada. Referimo-nos à Rhetorica Ecclesiastica de D. Caetano Barbosa. ${ }^{10}$

Aníbal Pinto de Castro sustenta que a leitura da Rhetorica Ecclesiastica, de D. Caetano Barbosa, apresentaria as bases do "método de pregar" português, isto é, os elementos fundamentais à definição do cânone estético da prosa barroca.

\section{A Rhetorica Ecclesiastica}

A obra Rhetorica Ecclesiastica apresenta três partes, apresentadas nesta ordem: invenção, disposição e elocução. As outras duas partes convencionais da retórica - memória e ação (ou pronunciação) - são comentadas no fim da terceira parte, sem lhe merecer tratamento especial. Vamos a elas, em ordem natural. ${ }^{11}$ Caetano Barbosa define a Retórica Eclesiástica como a arte de dizer com gravidade, de maneira ornada e abundante, a fim de

\footnotetext{
${ }^{8}$ Cf. MENDES. A oratória barroca de Vieira, p. 179-180.

${ }^{9}$ Cf. CASTRO. Retórica e teorização literária em Portugal: do Humanismo ao Neoclassicismo, p. 111.

${ }^{10}$ CASTRO. Retórica e teorização literária em Portugal: do Humanismo ao Neoclassicismo, p. 112. "Trata-se de uma obra manuscrita, hoje pertencente ao Fundo Geral da Biblioteca Nacional de Lisboa, onde figura com o número 3157”. (CASTRO. Retórica e teorização literária em Portugal: do Humanismo ao Neoclassicismo, p. 113.)

${ }^{11}$ Cf. CASTRO. Retórica e teorização literária em Portugal: do Humanismo ao Neoclassicismo, p. 112-128.
} 
persuadir o ouvinte/leitor. Essa definição integra-se já numa concepção estética barroca cujos traços se mostram claramente nos advérbios ornate e copiose. ${ }^{12}$

\section{INVENÇÃO}

Importa notar que, apesar de a primeira parte da Retórica Eclesiástica ser a invenção, o autor não inicia a obra diretamente por ela, o que seria natural e lógico. Inicialmente, discorre, de maneira deliberada, sobre tropos e figuras. Considerando que tropos e figuras são ornamentos da frase, esse roteiro - partir do ornamento para o estudo estrutural da frase e do discurso - configura uma atitude estética tipicamente barroca. Nessa concepção, na escrita do discurso, a própria escolha de uma palavra deve ter em vista tanto suas propriedades semânticas e sua clareza quanto o contributo que possa dar à expressão ornada e engenhosa de cada frase. ${ }^{13}$

Tropos e figuras são as bases necessárias para se estruturar os discursos religiosos. Naqueles, distingue os tropos de palavras dos de sentenças, mencionando, entre os primeiros, a metáfora, a sinédoque, a metonímia, a antonomásia, a catacrese e a metalepse. Entre os tropos de palavras, a metáfora lhe merece mais atenção, porque não se limita a defini-la distingue, com pormenor, os modos de formá-la, as causas de seu emprego, suas qualidades e vícios. Nos tropos de sentenças, inclui a alegoria, a perífrase, o hipérbato e a hipérbole. Seguem-se as figuras, que distingue dos tropos. Nestas, depois de considerar a divisão habitual em figuras de palavras e figuras de sentenças, apresenta uma classificação própria, baseada nos fins a que as mesmas figuras se destinam, a saber: agradar, provar, amplificar, mover os afetos e, em grupo à parte, as figuras próprias da arte concionatória.

Listadas as bases necessárias para estruturar o sermão, dedica-se, propriamente, a invenção. A base da invenção é constituída pelos argumentos, que podiam ser buscados aos lugares-comuns. Mas esses lugares de nada servem, se o pregador não souber utilizá-los de modo conveniente. Daí apresentar uma série de regras, destinadas a tal finalidade, conforme o gênero de discurso que se pretende compor, dado que o demonstrativo não revela as mesmas exigências do deliberativo, o judicial não podia acolher integralmente os preceitos do

${ }^{12}$ Cf. CASTRO. Retórica e teorização literária em Portugal: do Humanismo ao Neoclassicismo, p. 112-113.

${ }^{13}$ CASTRO. Retórica e teorização literária em Portugal: do Humanismo ao Neoclassicismo, p. 112114. 
didascálico ou doutrinal, nem o exornativo ${ }^{14}$ devia prescindir de regras específicas para a amplificação dos lugares. ${ }^{15}$

No quadro de argumentos próprios do gênero doutrinal (parte extensa da produção oratória da época), assumem especial relevo os afetos e os conceitos predicáveis. "Amor", “desejo”, “prazer”, “ódio”, “fuga”, “dor”, “esperança”, “desespero”, “medo”, “audácia” e "ira" são os 11 afetos por ele considerados. O pregador devia, porém, insuflar nos ouvintes apenas aquele afeto que, antecipadamente, escolhera como finalidade do sermão, tanto no seu conjunto quanto nas suas partes constitutivas. No recurso aos afetos, devia o pregador observar regras precisas e cuidadosamente enunciadas, em cuja formulação aparece, ainda, uma confessada preocupação de equilíbrio, clareza e apego ao real. O gosto barroco, porém, revela-se logo a seguir, no momento em que são anunciados os preceitos para a amplificação dos afetos e recomenda-se o uso abundante de epítetos, de gradações, de comparações e da ratiotinatio.

A outra grande fonte de argumentos eram os livros, especialmente os da Escritura e os dos santos padres, as coleções de apotegmas, provérbios e exemplos, tanto sagrados como profanos, bem como as obras de historiadores e eruditos. Na interpretação das passagens bíblicas, importava ter em conta o sentido literal e o místico, no qual se consideravam, ainda, o tropológico, o anagógico e o alegórico. Pelo uso apropriado desses vários sentidos, formava-se o conceito predicável - traço distintivo do método de pregar português -, que, apesar de já ter sido adotado anteriormente, aqui aparece definido pela primeira vez:

Conceptus igitur praedicatorius definitur artificiose expositio alicuius Scripturae confirmata sententia et dicto viri alicuius in ecclesia Dei celebris et cuius effectum namquam habent Auctoritatibus hic potes invenire in libris S.S.Patrum. ${ }^{16}$

Por essa definição, o conceito predicável é uma sentença engenhosa, tirada da Sagrada Escritura ou dos textos da Patrística, artificiosamente adaptada para servir de prova a determinada afirmação. Na adaptação do texto ao caso concreto que se queria provar, quanto maiores fossem a sutileza e o engenho demonstrados, maior seria a arte do pregador. Em sua

\footnotetext{
${ }^{14}$ Note-se que os gêneros tradicionalmente considerados eram o demonstrativo, o deliberativo e o judicial; mais raramente, acrescentava-se-lhes o didascálico ou doutrinal. Barbosa junta-lhes, ainda, o exornativo, da maior importância, porque nele estavam incluídos os panegíricos, tipo de discurso barroco por excelência. (Cf. CASTRO. Retórica e teorização literária em Portugal: do Humanismo ao Neoclassicismo, p.125, nota 125.)

${ }^{15}$ CASTRO. Retórica e teorização literária em Portugal: do Humanismo ao Neoclassicismo, p. 115.

${ }^{16}$ CASTRO. Retórica e teorização literária em Portugal: do Humanismo ao Neoclassicismo, p. 117.
} 
formulação, o essencial consistia em o orador descobri-lo invulgar e adaptá-lo, com argúcia, à ocasião.

As notícias que temos atribuem a sua invenção ao padre Francisco de Mendonça, da Companhia de Jesus. Essa paternidade é afirmada ao longo de todo o século $18 .{ }^{17}$ Foi, porém, a prática oratória de outro jesuíta, mais habilidoso e admirado, o padre Antônio Vieira, que consagrou o conceito predicável como elemento-base na construção do sermão barroco, tornando-o a pedra de toque do método de pregar português. O uso desse conceito foi tão profundo e generalizado que se elaboraram várias coleções em que os pregadores encontravam, ordenadas pelas letras do alfabeto, com segurança e sem grande trabalho, cópias abundante de provas e argumentos. ${ }^{18}$ Por vezes - como costuma acontecer, quando a arte faz concessões à moda, e o trabalho original se rende à cópia -, o hábito tornava-se pernicioso; sobretudo em autores menos talentosos, que inutilizavam o recurso com agudezas gratuitas.

Finalizam-se, aqui, nossas considerações sobre a primeira parte da Rhetorica Ecclesiastica, de Caetano Barbosa. Antes de passarmos à segunda parte - "Disposição" -, aprofundaremos a noção de "conceito predicável", com base em outra obra da época, a Nova Arte de Conceitos, de José Caetano.

\section{CONCEITOS PREDICÁVEIS ${ }^{19}$}

O conceito predicável permitia a exposição das verdades da fé e dos preceitos da moral por uma forma breve, sentenciosa e arguta, contanto que se respeitasse, como ponto de partida, a interpretação literal do texto bíblico e a clareza das palavras empregadas. Se bemformulado, a argúcia e a novidade que ostentava eram meios seguros para penetrar no espírito dos ouvintes, captar-lhes a atenção e dirigir-lhes as consciências. Se o orador não encontrasse a expressão adequada, porém, produziria uma rebuscada tapeçaria de figuras e tropos. ${ }^{20}$ Essa era uma das razões - já aventada acima - que induzia os pregadores a recorrerem a compêndios que lhes forneciam, com segurança, listas de conceitos.

${ }^{17}$ Cf. CASTRO. Retórica e teorização literária em Portugal: do Humanismo ao Neoclassicismo, p. 132.

${ }^{18}$ Cf. CASTRO. Retórica e teorização literária em Portugal: do Humanismo ao Neoclassicismo, p. 133.

${ }^{19} \mathrm{Na}$ elaboração do item "Conceito predicável", apoiamo-nos no capítulo 5, homônimo da obra Retórica e Teorização Literária em Portugal. (Lisboa: Imprensa Nacional-Casa da Moeda, 2008. p. 229-339), em que Aníbal Pinto de Castro resenha a parte da Nova arte de conceitos, de José Caetano, referente a conceito predicável.

${ }^{20}$ Cf. CASTRO. Retórica e teorização literária em Portugal: do Humanismo ao Neoclassicismo, p. 303. 
Havia outros obstáculos ao emprego proveitoso do conceito. Frequentes vezes, o recurso exclusivo à prova pelo conceito predicável tornava o discurso monótono, o que se procurava eliminar por meio de divisão, ainda que houvesse o risco de cair em excessos. Com a finalidade de marcar bem a estrutura do discurso, podia dividir-se e subdividir-se o sermão, o que, não raro, transformava-o num emaranhado confuso de partes que se desvinculavam umas das outras, comprometendo a unidade recomendada. Para evitar tais perigos, formularam-se preceitos que deviam guiar os pregadores na composição segura de conceitos predicáveis. A Nova arte de conceitos, de José Caetano, por exemplo, é representante modelar de obra destinada a esse fim. Nela, listam-se vários preceitos para os compor. ${ }^{21}$

A primeira condição para formar um bom conceito predicável é a escolha do texto apropriado da Sagrada Escritura. Eleito o texto, o passo seguinte consiste em dar-lhe forma e, para isso, deve-se interpretá-lo com segurança, observando-se os quatro sentidos possíveis que os textos bíblicos admitem - literal, alegórico, tropológico e anagógico. O sentido mais importante é o literal, visto que fundamenta todos os outros e, quando não é apreendido corretamente, compromete a estrutura e o significado de todo o edifício oratório. Com a finalidade de superar esse obstáculo, indicam-se modos de penetrar no sentido literal; por vezes, essas recomendações vinham acompanhadas de artifícios para ornar o texto.

Seguem-se nove modos para formar conceitos predicáveis. Em ordem, são: por adequação à natureza do assunto ou do tema, por reparo, por paradoxo, por mutação de palavras ou correção de sentenças, por correspondência de termos, por improporção ou dissonância de coisas e palavras, por combinação, por alusão e por apodo. Vamos a eles, na ordem em que foram listados. Na redação do conceito predicável, a primeira tarefa do pregador deve ser procurar uma naturalidade espontânea. O meio usual era disfarçar a sentença com alguma breve reflexão, mas de maneira que, parecendo filha da natureza, e não da arte, o único trabalho do pregador seria mostrar a beleza de sua face oculta.

O segundo modo de formar conceitos, e dos mais característicos, era o dos "reparos". Primeiro, citavam-se palavras ou períodos do texto bíblico; em seguida, faziam-se-lhe reparos, por meio de aposição de dúvidas, observações ou comentários.

O conceito formado por paradoxo consistia em enunciar uma proposição que contivesse termos em aparente contradição. O pregador, então, resolvia, com argúcia, as eventuais dúvidas dos ouvintes e revelava o nexo e a harmonia entre os termos da proposição.

${ }^{21}$ Cf. CASTRO. Retórica e teorização literária em Portugal: do Humanismo ao Neoclassicismo, p. 304-317. 
Na técnica denominada "correção de sentença", obtinha-se o conceito predicável após o cumprimento de etapas graduais. Primeiro, apresentava-se aos ouvintes um conceito preliminar, que atenderia as condições gerais de um conceito predicável, e confirmava-o com elegantes argumentos. Em seguida, rompendo a expectativa do ouvinte/leitor de que o primeiro conceito seria o predicável, propunha-se novo conceito, que reformulava o anterior (conceito preliminar), e, nessa função, era confirmado com argumentos ainda mais convincentes do que os primeiros. $\mathrm{O}$ artifício poderia terminar aqui, com a formulação do segundo conceito; mas o orador podia ir além e repetir a segunda etapa do processo, apresentando, então, um terceiro conceito, que seria o conceito predicável.

A formulação de conceitos por correspondência de termos consistia em apresentar uma proposição e explicitar a correspondência mais ou menos evidente entre os termos que a compunham. Essa técnica era oposta à do paradoxo, porque o nexo e a harmonia entre os termos da proposição estavam estabelecidos desde o início.

A técnica da dissonância visava a demonstrar a falta de harmonia ou improporção entre coisas e palavras presentes na proposição. Naturalmente, tal assimetria ocasionava circunstâncias úteis à matéria do sermão.

A técnica da combinação (ou comparação) consistia em confrontar de tal modo as coisas que umas brilhassem mais e desluzissem outras. O recurso empregado era o contraste dos termos, por meio de elementos vocabulares ou gramaticais dispostos paralelamente.

A técnica de compor conceitos por meio de alusão resumia-se a exprimir uma coisa de tal modo que fosse subentendida outra (coisa). Se entre o expresso e o subentendido houvesse acordo, proporção e harmonia, o conceito daí resultante seria, naturalmente, elegante e belo.

Por fim, a técnica do apodo estribava-se na adição a um termo de um qualificativo adequado, não necessariamente um adjetivo - podia ser um simples substantivo aposto, tomado em sentido metafórico.

Vimos, de modo breve, os nove modos mais comuns de formar conceitos predicáveis. Além deles, havia outros, que podiam ser obtidos de várias maneiras - seja combinando alguns dos procedimentos listados, seja formulando maneiras novas de os compor.

Voltemos à Rhetorica Ecclesiastica, de D. Caetano Barbosa.

\section{DisPosição}

$\mathrm{Na}$ disposição, o primeiro ponto que deveria ser considerado era o estabelecimento da proposição. Uma proposição, para ser considerada perfeita, deveria ser una, clara e completa, isto é, deveria encerrar tudo que seria desenvolvido no sermão. Poderia, além disso, conter 
algo útil, visando à formação moral dos ouvintes. Tal conteúdo, que deveria ser, de preferência, especulativo, devia procurar excitar um afeto suscetível de perdurar no espírito do auditório e não negligenciar as circunstâncias de lugar, tempo, orador e ouvintes. Finalmente, tinha de ser conforme ao Evangelho e apresentar sempre novidade. Esse último ponto revestia-se de tal importância que o autor formula um conjunto de regras destinadas a habilitar o pregador à sua obtenção, como, por exemplo: a transformação do certo em problemático; o recurso à comparação; e o uso de paradoxos.

Relacionada à novidade, e contribuindo para a caracterização barroca da eloquência sacra desse período, vinha, a seguir, a "variedade", baseada, principalmente, na metáfora. Acresça-se, porém, que o recurso à linguagem metafórica lhe merece restrições, quando usada nos panegíricos de santos.

A vastidão de assuntos leva o autor ao problema da divisão. Cada gênero de discurso exigia um tipo diferente de divisão, embora houvesse certas condições, de caráter geral, às quais o pregador, ao estabelecê-la, devia cuidadosamente obedecer; assim, as partes do sermão não podiam colidir umas com as outras; as digressões só eram admissíveis se se relacionassem com os assuntos principais tratados no sermão; a divisão da matéria não devia alongar-se por mais de três ou quatro capítulos; e o orador não podia versar aspectos que não tivessem sido enunciados ao estabelecê-la. Além disso, a ordem por que as várias partes haviam sido apresentadas não podia ser alterada no decurso do sermão, e devia prescindir dos lugares-comuns de menor valor probativo, sobretudo se pretendia apenas aumentar, com eles, a extensão do texto. A divisão tinha, ainda, que se fazer de modo que todos os seus pontos pudessem deduzir-se facilmente do Evangelho, segundo uma ordem compatível com os textos colhidos na Sagrada Escritura. ${ }^{22}$

A ordenação de argumentos podia ser discursiva ou fazer-se por meio de acumulação sucessiva de conceitos. Recomendava-se, num e noutro caso, apresentar primeiro os argumentos que pudessem contribuir para o entendimento dos restantes; e, por outro lado, iniciar e terminar a argumentação pelos argumentos mais fortes, deixando os mais frágeis no meio. Tornava-se, no entanto, evidente que todas as preferências do autor iam para o segundo daqueles métodos e, por isso, as normas relativas à ordenação dos conceitos lhe mereceram longa pormenorização. ${ }^{23} \mathrm{Na}$ disposição dos conceitos havia que se ter o maior cuidado em não

${ }^{22}$ Cf. CASTRO. Retórica e teorização literária em Portugal: do Humanismo ao Neoclassicismo, p. 118-119.

${ }^{23}$ Cf. CASTRO. Retórica e teorização literária em Portugal: do Humanismo ao Neoclassicismo, p. 121. 
perder de vista os cinco aspectos seguintes: sua qualidade, o lugar que devem ocupar, sua explicação, sua conexão mútua e sua amplificação.

Havia três espécies principais de conceitos: os imagináveis, que serviam para deleitar; os morais, para ensinar; e os imediatos, para comover. Além dessas, importa ainda mencionar as classes formadas, uma a uma, por díades cujos elementos são termos antitéticos: especulativos e morais, necessários e prováveis, literais e místicos, históricos e elementares, fáceis e difíceis, dependentes e independentes, sutis e simples, universais e particulares, mediatos e imediatos, e fortes e fracos.

Quanto ao lugar que lhes cabia na oração, indica uma ordem segundo a qual viriam primeiro os conceitos ad delectandum (para deleitar), depois os tropológicos, ad docendum (para ensinar), e, por fim, os destinados ad movendum (para mover). O ideal seria reunir conceitos para deleitar, ensinar e mover num mesmo discurso, mas deviam prestigiar-se os que se relacionassem com a finalidade primacial do sermão, enriquecendo-os com razões sólidas e bem fundamentadas.

Para explicar o conceito usado, não era conveniente insistir nas partes em que a beleza se mostrava mais fácil; era melhor ir demonstrando o próprio artifício e os meios com os quais atingira aquela beleza e novidade. A explicação podia, também, fazer-se pela dúvida, demonstrando a própria dificuldade do conceito. Essa explicação admitia vários modos; mas Caetano Barbosa limitou-se a indicar apenas dois: no primeiro, propunha-se o assunto que se queria provar, aduzia-se o texto sobre o qual se fundamentava o conceito, discorria-se sobre esse texto e formulavam-se dúvidas, mostrando as inadequações ou contrariedades que se supunha existirem nele como sendo capazes de destruir a proposição apresentada. Após esclarecer os ouvintes, resolviam-se as dúvidas, recorrendo-se à autoridade dos santos padres, para, depois, sem maior demora e sem repetir o que estava dito, aplicar o conteúdo conceituoso aos fatos ou pessoas, por meio de símiles e de outros recursos. O segundo modo era mais simples. Definido o ponto a ser provado, aduzia-se o texto e formulavam-se as dúvidas por ele suscitadas, que seriam resolvidas, com clareza, por meio de conhecimentos teológicos ou filosóficos. Resolvida a dificuldade, invocava-se uma autoridade para corroborar a solução apresentada.

Caetano Barbosa tratava, por fim, da amplificação de conceitos. As funções fundamentais da amplificação eram: tornar os argumentos mais veementes e aumentar ou diminuir os fatos, fazendo grandes coisas que pareciam pequenas, ou minimizando as que pareciam grandes. O meio usual, para isso, era recorrer a nomes, palavras ou coisas que possuíssem qualidade ou propriedade de aumento. Para amplificar por palavras, bastava 
acrescentar aos já ditos, novos significantes de mesmo significado, porém mais expressivos e mais fortes. Para amplificar pelas coisas, podia recorrer-se aos adjuntos e circunstâncias do que já se dissera, ou a certos modos de narrar e expor, descendo do gênero à espécie e do geral ao particular. ${ }^{24}$

\section{ESTRUTURA DOS SERMÕES}

Estudada a disposição dos argumentos, o autor versava a estrutura dos sermões, pormenorizando e normatizando o esquema (que retomou) apresentado por Antônio Vieira, no Sermão da Sexagésima. Também aqui, o sermão se apresenta composto de exórdio, narração, confirmação (e confutação) e epílogo ou peroração.

Barbosa lista três espécies usuais de exórdio. Na primeira, o exórdio visava apenas enunciar o assunto do sermão e mostrar a finalidade do orador ao pregar naquele determinado lugar e tempo. Devia formar-se a partir de texto dos evangelistas e podia obter-se de tantos modos quantos os que permitiam narrar o Evangelho. Na segunda, o exórdio continha uma espécie de remédio contra os vícios que, a seguir, o orador iria discutir. Nesse caso, formavase elaborando uma resposta prévia a possíveis objeções contra as afirmações produzidas pelo pregador. $\mathrm{Na}$ terceira classe, não só se enunciava a matéria do sermão, como também se procurava conciliar a benevolência e a atenção do auditório. Nessa espécie, o exórdio podia deduzir-se não só da própria matéria, apresentando-a admirável, sublime e útil, mas também da pessoa do orador, posta em relação com o auditório, a ocasião, o lugar ou outras circunstâncias oportunas.

Havia outras maneiras para se formar exórdios. Com base no recurso empregado em sua formulação, Barbosa distingue outras três: comparação, circunstâncias e amplificação. Na elaboração de exórdios por comparação, havia dois caminhos convencionais: iniciava-o por uma conjunção comparativa, deixando os ouvintes suspensos, para, depois, explanar os termos postos em confronto; e enunciavam-se, de uma só vez, todos os termos da comparação. No segundo modo, focaliza-se alguma circunstância vinculada ao sermão, isto é, a pessoa do pregador, o auditório, o lugar, a ocasião, o tempo, entre outras circunstâncias. O orador podia aproveitá-lo (esse exórdio) para desfazer, nos espíritos dos ouvintes, obstáculos que, eventualmente, os impedissem de acolher a prédica com benevolência e atenção. Nele (no exórdio), eram frequentes o ornato e a amplificação, que não deviam faltar a parte tão importante do discurso. Se a proposição inicial contivesse algum paradoxo, aproveitar-se-ia o

${ }^{24}$ Cf. CASTRO. Retórica e teorização literária em Portugal: do Humanismo ao Neoclassicismo, p. 119-121. 
exórdio para explicá-lo; mas, se contivesse algum fato histórico, sentença ou exemplo, aproveitá-lo-ia para estabelecer seu nexo com a matéria do discurso. Finalmente, havia exórdios desenvolvidos a partir de amplificação. Nesse caso, recorria-se à enumeração ou à pormenorização do conteúdo de uma proposição inicial.

Cada ocasião pedia um exórdio específico. Por exemplo, nas solenidades mais importantes, em que o auditório estivesse sob o domínio de grandes sentimentos - Natal, Páscoa, Pentecostes, Exéquias, etc. -, seria preferível iniciar o exórdio ex abrupto, incluindo nele algumas argúcias e afetos, para explicar os mistérios celebrados e lamentar a magnitude dos sentimentos suscitados pela própria natureza deles.

Todos esses modos de compor exórdios estavam, porém, sujeitos a certo número de regras e condições. A atenção dos ouvintes devia captar-se logo no início do exórdio, o que se obtinha conferindo novidade e beleza à proposição inicial; a sua benevolência obtinha-se por meio de proposição agradável e demonstrando-lhes reverência e afeto; e a docilidade obtinhase pela escolha de proposição justa e pela adoção de divisão clara.

O exórdio não deveria ser comutável, isto é, adaptável a qualquer outro sermão, nem encerrar qualquer elemento contrário às finalidades procuradas pelo orador.

Entre as figuras mais adequadas à parte inicial da oração, eram preferíveis a dubitatio, ${ }^{25}$ a suspicio, ${ }^{26}$ a licença, a distributio, ${ }^{27}$ a antítese (sobretudo nos panegíricos), a reticência, a apóstrofe, a exclamação e a interrogação.

Se, no corpo do discurso, o orador empregasse metáforas cultas, sentenças brilhantes e agudezas, convinha, por outro lado, que o estilo do exórdio fosse médio, para dar equilíbrio ao discurso e permitir aos ouvintes ascenderem, gradualmente, ao cume do edifício oratório. Quanto ao movimento, preconizava que fosse suave (lenis), na expressão dos sentimentos de alegria, e quase lento (inchoatus), nos mais graves. ${ }^{28}$

As qualidades imprescindíveis à boa narração, nesta ordem, eram: brevidade, clareza, probabilidade, energia ou evidência e elegância. A brevidade tornava o discurso inteligível, e obtinha-se evitando informações supérfluas ou mencionadas anteriormente. A clareza facilitava o entendimento do texto e alcançava-se expondo os fatos de maneira ordenada e atribuindo a cada um tempos, lugares, pessoas ou circunstâncias próprias, o que evitava

\footnotetext{
${ }^{25}$ dubitatio: "causar dúvida", "reflexão".

${ }^{26}$ suspicio: "conjectura", "hipótese".

${ }^{27}$ distributio: "divisão", "distribuição".

${ }^{28}$ CASTRO. Retórica e teorização literária em Portugal: do Humanismo ao Neoclassicismo, p. 122124.
} 
parênteses e sentidos ambíguos. A probabilidade identificava-se à verossimilhança; isto é, à ligação harmônica entre ideias ou fatos. A energia consistia em mostrar os fatos com tal enquadramento e de tal maneira que os ouvintes acreditassem vê-los e ouvi-los representados. A elegância relacionava-se à agudeza na exposição de ideias, motivos e fins dos fatos narrados; e obtinha-se intercalando coisas belas nas passagens menos agradáveis, o que evitava particularidades descritivas sempre enfadonhas.

Os modos de narrar organizavam-se de quatro maneiras: um modo era representar ao auditório tudo quanto se poderia captar com os olhos e ouvidos; para isso, o orador recorria a todas as circunstâncias e detalhes sugeridos pela matéria do discurso; outro modo era contar os acontecimentos pretéritos como se fossem presentes; um terceiro modo de narrar era, tratando de mortos, evocá-los como se estivessem vivos e fossem atuantes, o que conferia maior evidência à narração; por fim, podiam imitar-se coisas diversas por palavras ou modos, sobretudo por onomatopeia, para obter evidência enérgica.

Havia três gêneros de narração: a exornativa, própria dos panegíricos; a trágica, em ocasiões solenes e de sentimentos tristes; e a espirituosa (lepida), para provocar o riso.

A narração de fatos obscuros ou a descrição de pensamentos difíceis solicitava um estilo claro e direto; a narração de fatos evidentes, por outro lado, sobretudo no gênero demonstrativo, permitia empregar histórias ou fábulas, apresentadas com sutileza. Nesse caso, as figuras próprias ao estilo eram: hipotipose, reticência, exclamação, admiração e interrogação, entre outras.

Seguem-se a confirmação (e a confutação). Na confirmação, empregavam-se argumentos derivados de razões e consequências apresentadas; ou seja, de lugares-comuns, de tópicos e de textos da Bíblia ou dos santos padres, por meio de conceitos predicáveis. Os textos bíblicos deviam ser utilizados abundantemente, mas sempre na versão latina da Vulgata (e não traduzidos, embora fosse admitida a paráfrase subsequente à citação). A ordem na apresentação dos argumentos devia obedecer às mesmas normas propostas para os conceitos predicáveis.

A confutação revelava grande importância, sobretudo nos sermões morais, em que o método dialético pressupunha a desconstrução de objeções de um pretenso adversário. Nesse caso, a ordem na disposição de seus argumentos era a que o adversário seguia na sua confirmação. ${ }^{29}$

\footnotetext{
${ }^{29}$ CASTRO. Retórica e teorização literária em Portugal: do Humanismo ao Neoclassicismo, p. 124-
} 126. 
O sermão terminava com o epílogo (ou peroração), que não podia ser tão longo, que parecesse novo sermão, nem tão breve, que deixasse esquecido algum dos pontos principais tratados. Nos sermões curtos ou que versassem poucos assuntos, podia mesmo dispensar-se, substituindo-o por uma breve conclusão. O epílogo devia, pois, conter uma súmula dos pontos enumerados ao longo do discurso, de modo a constituir uma sequência lógica da proposição e, por outro lado, não ser tão claro que parecesse uma repetição dos argumentos já aduzidos.

Para amplificar e mover os afetos - finalidade essencial do epílogo -, recomendava-se empregar algumas figuras especialmente destinadas a conferir nobreza e novidade ao fecho do sermão, como, por exemplo, a ironia, a exclamação, a interrogação e a apóstrofe. Se os afetos tivessem sido postos em movimento no corpo do sermão, empregava-se o chamado epílogo ex abrupto, mais impetuoso e contundente. ${ }^{30}$

\section{ELOCUÇÃO}

Na elocução, citavam-se as três espécies canônicas de estilo: o baixo, o médio e o sublime. $\mathrm{O}$ estilo baixo imitava a fala familiar, e devia reservar-se às cartas e à narração, sem emprego de figuras veementes e ornato retórico. O médio admitia recursos retóricos que ornassem, moderadamente, as sentenças, pois a exuberância metafórica e as figuras que mais contribuíam para a riqueza estilística ainda the estavam vedadas. $\mathrm{O}$ estilo sublime, próprio à amplificação e à excitação dos afetos, caracteriza-se pela abundância de figuras enérgicas $a d$ amplificandum (para amplificar), em cujo número se contavam as exclamações, as interrogações vigorosas e, ainda, outras. Naturalmente, o estilo sublime era expresso por período solene e suas partes eram ligadas por numerosas partículas conjuntivas. ${ }^{31}$

O meio ideal para adquirir um estilo perfeito era a imitação, de particular alcance na invenção, disposição e elocução. Havia várias técnicas de imitação: alterar a forma de uma sentença, preservando-lhe o conteúdo; alterar o conteúdo ou o sentido, mantendo a expressão verbal básica; fazer acréscimos ao conteúdo (ou à forma) tomado(a) do modelo, conservando a mesma ordem das palavras; empregar as mesmas figuras em novas sentenças e palavras; e, finalmente, usar as mesmas argúcias com os mesmos argumentos, mas aplicando-os a outros objetos.

Para aperfeiçoar o discurso, recomendavam-se três processos: enriquecê-lo com palavras e sentenças adequadas, empregando os mesmos vocábulos na exposição dos mesmos

\footnotetext{
${ }^{30}$ CASTRO. Retórica e teorização literária em Portugal: do Humanismo ao Neoclassicismo, p. 126.

${ }^{31}$ CASTRO. Retórica e teorização literária em Portugal: do Humanismo ao Neoclassicismo, p. 126127.
} 
assuntos, mas de maneira diferente e elegante; procurar a gravidade do estilo, evitando os vícios da linguagem metafórica e aprofundando o conteúdo com provérbios, fábulas ou fatos históricos; e recorrer à agudeza, para formalizar sentenças que abrigassem sutilezas e metáforas cultas.

As virtudes da oração perfeita eram quatro: a correção, que se alcançava respeitandose as regras gramaticais e evitando-se as formas vocabulares contrárias à "norma" culta, para o que contribuía a leitura de autores clássicos; a perspicuidade, oposta à obscuridade; o ornato, que conferia beleza ao período; e a adequação; isto é, fazer cada um falar de acordo com sua condição. ${ }^{32}$

Com alguns preceitos referentes à memória, à pronunciação e às qualidades morais do pregador, termina-se a Rhetorica Ecclesiastica, de Caetano Barbosa, cujos pontos principais foram aqui sumariados.

\section{SÍNTESE DO MÉTODO DE PREGAR PORTUGUÊS}

Para A. Pinto de Castro, a Rhetorica Ecclesiastica abarca o aparato teórico que orientou a elaboração de discursos religiosos "na primeira fase do barroco":

(...) [a obra] contém a teoria que pautou a actividade dos púlpitos portugueses na primeira fase do barroco, transmitida, pelo seu carácter pedagógico, a sucessivas gerações de alunos, que não só a aplicavam ao pregar, como, por exemplo, a ministravam quando mais tarde eram chamados a ensinar. Deste modo, encontramos ao longo da sua leitura uma valiosa série de elementos que se nos afiguram fundamentais para a definição do cânone estético de um dos gêneros mais ricos da nossa prosa barroca - a parenese. ${ }^{33}$

Nessa passagem, o historiador da retórica propõe que essa obra ostenta uma série de elementos que teriam definido o cânone estético que orientou a prática oratória em Portugal (e, naturalmente, nas colônias portuguesas) "na primeira fase do barroco". Vejamos como.

A elocução e o ornato retórico assumiram maior prestígio, como fica patente na prioridade concedida ao estudo dos tropos e das figuras no esquema geral da obra. Esse caráter prioritário é tão evidente que, só após o estudo dos tropos e figuras, tratou da análise estrutural do discurso. Mesmo aqui, continuava a recomendar que a escolha de palavras obedecesse ao critério da propriedade, da clareza e do contributo que elas pudessem trazer ao

${ }^{32}$ Cf. CASTRO. Retórica e teorização literária em Portugal: do Humanismo ao Neoclassicismo, p. 128.

${ }^{33}$ CASTRO. Retórica e teorização literária em Portugal: do Humanismo ao Neoclassicismo, p. 128129. 
ornato. Partindo do ornato para a disposição, considerou aquela preocupação constante e, quando tratou deste último aspecto, fez dele (ornato) a base de todas as atenções do orador. Por essa opção, bem sintomática da estética barroca, o delectare prevalecia claramente sobre o docere, no conjunto das finalidades do pregador. Nota-se que o processo principal da invenção retórica era a amplificação, que determinaria o estabelecimento de uma classe de figuras e de regras específicas, quando aplicadas aos lugares-comuns e aos afetos. A amplificação forneceu um dos melhores processos para atingir a arborescência ${ }^{34}$ que, tanto no conteúdo quanto na forma, constituía uma das marcas distintivas da oratória barroca. A riqueza proveniente da amplificação não era, no pensamento estético do barroco, incompatível com a clareza. No entanto, a variedade de conteúdo, expressa com elegância e em grande número, solicitava uma estrutura que conciliasse a ordem expositiva e a nobreza arquitetônica convenientes à exuberância do estilo, para manter a clareza indispensável à matéria versada. ${ }^{35}$

A divisão do sermão em partes convencionais - tema latino, proposição, exórdio, narração, confirmação (e confutação) e peroração - cada uma delas sujeita a normas específicas - produziu o edifício estrutural da parenética portuguesa ao longo de todo o século 17. Esse esquema, proveniente da interpretação quinhentista dos esquemas retóricos da Antiguidade (em especial dos de Cícero), constituiu-se num processo seguro de conferir clareza e harmonia ao sermão. ${ }^{36}$ Simultaneamente, essa divisão imprimiu nos oradores hábitos que vieram a se constituir nos caracteres definidores do método de pregar português. $\mathrm{O}$ primeiro desses hábitos é o uso de um único tema latino, sobre o qual se formava a proposição (conceito predicável). O tema, enunciado, indispensavelmente, em Latim, surge como o verdadeiro ponto de origem de todo o sermão. Outro desses hábitos é a necessidade da divisão, ditada pela grande extensão e abundância das provas, mas cuidadosamente regulamentada por um conjunto de preceitos moderadores que impediam o pregador de fragmentar, excessivamente, a matéria, o que comprometeria a clareza e a harmonia do discurso. ${ }^{37}$

${ }^{34}$ Cf. BARTHES. Sade, Fourier, Loyola, p. 35-81. Na descrição do modo pelo qual o discurso religioso inaciano se expande ou ramifica, Roland Barthes emprega e analisa o termo "arborescente".

${ }^{35}$ Cf. CASTRO. Retórica e teorização literária em Portugal: do Humanismo ao Neoclassicismo, p. 129-131.

${ }^{36}$ Cf. CASTRO. Retórica e teorização literária em Portugal: do Humanismo ao Neoclassicismo, p. 131.

${ }^{37}$ Cf. CASTRO. Retórica e teorização literária em Portugal: do Humanismo ao Neoclassicismo, p. 131-132. 
A confirmação assentava em provas e argumentos e, quando enriquecidos com citações em Latim da Vulgata ou dos padres, adquiria maior solenidade e valor probativo como fator capaz de impressionar os auditórios. ${ }^{38}$

A existência desse método, porém, não é consensual entre os estudiosos do barroco português. Margarida Vieira Mendes, ${ }^{39}$ por exemplo, contesta a tese, defendida por A. Pinto Castro, de que o Sermão da Sexagésima conteria uma nova teoria retórica; isto é, um método distinto de pregar que viria a chamar-se "português". ${ }^{40}$

Vejamos, em linhas gerais, a refutação à tese de um método de pregar português.

\section{UM “MÉTODO PORTUGUÊS”?}

Segundo Margarida Vieira Mendes, parece que Antônio Vieira não escreveu uma "Arte de pregar", nem qualquer outro tratado de retórica. Tal fato, porém, não diminui a influência que a obra de Vieira exerceu na maneira de pregar de seus contemporâneos:

Não restam dúvidas de que a influência da obra oratória do padre Vieira foi decisiva a partir da segunda metade do século XVII. Todos os testemunhos são unânimes. Mas não por os pregadores se reclamarem de programas cancionatórios específicos, explicitados no S. Sexagésima; antes por terem imitado a prática cancionatória de Vieira. (...) Se existiu um método de pregar cujo expoente passou a ser a obra de Vieira, não é o S. Sexagésima o responsável pela sua invenção, ou sequer pela sua proposição e divulgação. Pelo contrário. Mas já o será a obra Sermoens em doze tomos. O S. Sexagésima não propôs um método, mas apresentou a imagem ou retrato, a "vera efígie" de um protótipo de pregador apostólico; a qualidade literária dos sermões desse pregador, o conhecimento da sua personalidade e a actuação pública e histórica não fizeram mais do que avivar e dar corpo a tal imagem. ${ }^{41}$

Margarida Vieira Mendes admite a existência de um "método de pregar" português; mas - acolhendo que tenha existido - contesta-lhe a origem proposta por A. Pinto de Castro. Se houve um "método" - pondera M. Vieira $\operatorname{Mendes}^{42}$-, ele não teria sido formulado no Sermão da Sexagésima; mas, possivelmente, divulgado no conjunto da obra sermonística, em

\footnotetext{
${ }^{38}$ Cf. CASTRO. Retórica e teorização literária em Portugal: do Humanismo ao Neoclassicismo, p. 132-133.

${ }^{39}$ Cf. MENDES. A oratória barroca de Vieira, p. 178-191.

${ }^{40}$ Cf. MENDES. A oratória barroca de Vieira, p. 178.

${ }^{41}$ MENDES. A oratória barroca de Vieira, p. 178.

${ }^{42}$ Cf. MENDES. A oratória barroca de Vieira, p. 178.
} 
12 tomos, preparada, por Vieira, entre 1679 e 1697, ano de sua morte. ${ }^{43}$ A justificativa é esta: o Sermão da Sexagésima não apresentou um novo método de pregar, mas a imagem, o ethos do pregador evangélico ideal. A qualidade retórico-literária inegável do conjunto da obra de Vieira teria, então, de forma natural, consolidado e disseminado tal imagem. ${ }^{44}$ Essa é a tese da pesquisadora. Logo, Vieira teria seguido um método de pregar já em voga em Portugal à época em que pregou.

Margarida Vieira Mendes não descarta, porém, a existência de um método: “A haver um 'método', ele foi aplicado e difundido por Vieira, mas não inventado por si e não exposto de modo coerente e programático no S. Sexagésima." 45

Se houve um "método" distinto de pregar, ele não teria sido inventado por Vieira, mas "aplicado e difundido" por ele em sua obra. Essa hipótese retira de Vieira a formulação de um modelo distinto de pregação. Não fica claro, no texto da pesquisadora, mas infere-se dele que a prática oratória de Vieira faça parte de um processo histórico que resultou na constituição de um método de pregar português e jesuítico. Nesse caso, as obras sermonísticas de outros autores, como, por exemplo, de Antônio de Sá, poderiam ajudar-nos a estabelecer as características desse "método".

Vamos, passo a passo, à refutação de Margarida Vieira Mendes à tese de A. Pinto de Castro.

Inicialmente, ela retoma, formalmente, a definição que o pesquisador propõe para esse "Método", para contestá-la, a seguir:

\begin{abstract}
A teoria expressa no Sermão da Sexagésima contém, nas suas censuras e nas suas afirmações, a base do "método" que há-de vir a chamar-se "português". Apresenta e aplica o mesmo esquema de desenvolvimento e a mesma estrutura das diversas partes que nele hão-de ser consideradas essenciais: o uso do tema latino, o exórdio, a definição da matéria e a sua divisão, a confirmação baseada em provas, exemplos ou textos e, finalmente, a peroração. ${ }^{46}$
\end{abstract}

E, ainda:

Fiel a um esquema básico diretamente recebido dos teorizadores clássicos quinhentistas, o sermão ideal de Vieira faz, no entanto, generosas concessões

\footnotetext{
${ }^{43}$ A edição príncipe dos sermões de Antônio Vieira compreende quinze volumes - os 12 primeiros foram preparados pelo próprio pregador; os três restantes são póstumos e foram organizados por André de Barros.

${ }^{44}$ Cf. MENDES. A oratória barroca de Vieira, p.178.

${ }^{45}$ MENDES. A oratória barroca de Vieira, p. 179.

${ }^{46}$ Castro, 1973, p. 107, citado por MENDES. A oratória barroca de Vieira, p. 179.
} 
ao gosto barroco, precisamente pelo lugar que, na sua construção, é reservado à amplificação e pelo papel que nele desempenha o conceito predicável. Além disso a conjugação da unidade com a variedade. ${ }^{47}$

Margarida Vieira Mendes sugere que os traços do Sermão da Sexagésima, apresentados por Aníbal Pinto de Castro, não são específicos de um novo método de pregar. Primeiramente, o esquema de desenvolvimento ou a "estrutura das partes", das quais consta a divisão, tem sua origem e correspondência nos mais antigos manuais de retórica. Já no Ad Herenium são seis as partes aconselhadas: exórdio, narração, divisão, confirmação, refutação e peroração. Por sua vez, o "tema latino", retirado da Bíblia, sempre foi utilizado na homilia cristã, desde a Idade Média. ${ }^{48}$

O "conceito predicável" de que Vieira se valeu, constantemente, tal como todos os pregadores ibéricos, pois era o método demonstrativo em voga e de maior mérito na eloquência sagrada, não foi proposto por Vieira. Além disso, o conceito predicável usado como procedimento argumentativo e como método de construção de um discurso copioso não constitui invenção de Vieira. Ainda que as informações sobre a sua origem divirjam, todas apontam para períodos anteriores. ${ }^{49}$

No que se refere à conjunção "unidade"/“diversidade", própria da estética barroca - e, segundo A. P. de Castro, especifica do método de pregar português -, tornou-se, de fato, apanágio das obras de Vieira, mas já existia nos sermões do pregador espanhol Paravicino ou do português Francisco de Mendonça e coincide com certas propostas mais pragmáticas apresentadas no Sermão da Sexagésima. No entanto, não foi Vieira quem o inventou, nem o podemos considerar o único esquema de sermão que, então, vigorou em Portugal. ${ }^{50}$

A unidade baseada numa só proposição era preceito estabelecido por Francisco Panigarola, famoso pregador italiano do século XVI. Ele se mostrava contrário à pregação que, tendo de comentar o Evangelho, cláusula a cláusula, não se propusesse a integrar os comentários numa proposição que os ligasse; ou seja, opunha-se ao sermão apostilado. ${ }^{51}$

Se reunirmos a declaração de Vieira no prólogo ao "Leitor", ao falar de um novo tipo de pregação introduzida por ele - “(...) o rumo particular, que segui sem outro exemplo,

\footnotetext{
${ }^{47}$ Castro, 1973, p. 98, citado por MENDES. A oratória barroca de Vieira, p. 179.

${ }^{48}$ Cf. MENDES. A oratória barroca de Vieira, p. 179.

${ }^{49}$ Cf. MENDES. A oratória barroca de Vieira, p. 180.

${ }^{50}$ Cf. MENDES. A oratória barroca de Vieira, p. 181-182.

${ }^{51}$ Cf. MENDES. A oratória barroca de Vieira, p. 182.
} 
porque só dos que são dignos de imitação se fizeram os Exemplares." ${ }^{2}$ - aos ataques que, no capítulo 6 do Sermão da Sexagésima, dirige a um modo de pregar então muito em voga na época, que define pela técnica da apostila, ${ }^{53}$ seríamos levados a pensar que, antes de Vieira, praticava-se, em Portugal, unicamente o sermão apostilado ${ }^{54}$ e que, a partir dele, introduz-se o sermão de tema único e construção rigorosa.

A produção oratória, porém, no primeiro quartel do século 17 - tanto em Portugal, como atesta a obra do padre Francisco de Mendonça, quanto em Espanha, como se verifica nas prédicas do seu contemporâneo, o famoso Hortêncio Félix Paravicino -, revela que o método exercitado na Península Ibérica não se limitava ao da apostila, ou do simples comentário textual; já, então, praticava-se o sermão de tema latino, com um único assunto proposto, abarcando divisão arborescente em motivos variados. ${ }^{55}$

O método apostilado era encontrado na Itália, ao longo do século XVI; e manteve-se, em Portugal, ainda no século 17. Segundo Frei Luís de Sousa, o introdutor do método de pregar apostilado em Portugal teria sido o dominicano Antônio da Fonseca, pregador de D. João III. Com esse método, pretendia simplificar e tornar mais acessível e apostólico o discurso religioso, visto que a argumentação seria mais colada às Escrituras Sagradas e menos dialética e retórica. O sermão apostilado seguiria, cláusula a cláusula, o Evangelho, adicionando, sintagmaticamente, cada discurso, a fim de consolidar um programa pedagógico, eficaz e apostólico, presente no próprio texto das Escrituras. Consistia em pregar, sobretudo, o sentido literal, e de modo mais "fácil", pois o orador não necessitava obedecer aos preceitos clássicos das partes da oração, nem aos reparos e provas. O sermão seria, naturalmente, menos erudito e elegante, necessitando, como compensação, de alguns ornamentos. Assim aconteceu e, em breve, o que era simples paráfrase de passagens bíblicas tornou-se um longo desfile tópico de trechos copiados de variadas fontes intertextuais. ${ }^{56}$

\footnotetext{
${ }^{52}$ VIEIRA. Sermões: I, p. 6.

53 "Usa-se hoje o modo, que chamam de apostilar o Evangelho, em que tomam muitas matérias, levantam muitos assuntos: e quem levanta muita caça, e não segue nenhũa, não é muito que se recolha com as mãos vazias. Boa razão é também esta. O Sermão há-de ter um só assunto, e ũa só matéria." VIEIRA. Sermões: I, p. 44.

54 "O sermão apostilado consistia em aglomerar explicações no próprio corpo do texto, tornando-o uma floresta de anotações que obscurecia a compreensão do essencial." (VIEIRA. Sermões: I, p. 44, nota 60 .)

${ }^{55}$ Cf. MENDES. A oratória barroca de Vieira, p. 182.

${ }^{56}$ Cf. MENDES. A oratória barroca de Vieira, p. 183.
} 
Os jesuítas detinham boas condições para contestar esse método apostilado, dada a sólida formação retórica de seu ensino humanístico, que, em Portugal e em suas colônias, nunca abandonou o caráter escolástico e a herança clássica do discurso planificado, dividido e com provas. Com sua contraproposta - o sermão de um só assunto e uma única matéria -, Vieira parece propor um outro modelo de sermão. O pregador não fala em proposição, mas em matéria ou assunto. No entanto, a matéria do discurso reduzia-se, frequentes vezes, a uma proposição, o que aproxima "matéria" e "proposição". De tal modo, a fala de Vieira não deve ser considerada a inauguração de um método novo. ${ }^{57}$

Haveria, portanto, pelo menos dois "métodos de pregar" portugueses: o sermão apostilado, vinculado à exegese ou ao comentário patrístico; e o sermão de um só tema, proveniente da escolástica medieval unida à restauração humanista e letrada de caráter clássico. $^{58}$

Essa questão está longe do fim. Porventura, a edição da obra de autores contemporâneos a Vieira - como a de Antônio de Sá - ajude os críticos a iluminar um pouco essa discussão. Tais obras poderiam ampliar a compreensão das técnicas de pregação e revelar comentários a respeito dos fundamentos que direcionaram a atividade cancionatória seiscentista. De resto, o fato de haver "método" no pregar é inegável, mas daí a haver um único "método" é tese a se confirmar ou não.

\section{RESUMEN}

Este artículo presenta, en líneas generales, el esquema retórico que parece haber disciplinado la elaboración de discursos religiosos en Portugal y en la América Portuguesa en la primera fase del Barroco: el método portugués de predicar. Algunas características de ese método serán listadas y ejemplificadas con base en los sermones de Antonio de Sa (1620-1678), autor considerado uno de los modelos de la parenética barroca practicada en la América Portuguesa.

\section{Palabras Clave}

Literatura brasileña, prosa barroca

\footnotetext{
${ }^{57}$ Cf. MENDES. A oratória barroca de Vieira, p. 183.

${ }^{58}$ Cf. MENDES. A oratória barroca de Vieira, p. 183.
} 


\section{REFERÊNCIAS}

BARTHES, Roland. Sade, Fourier, Loyola. Trad. Mário Laranjeira. São Paulo: Martins Fontes, 2005. $225 \mathrm{p}$.

CASTRO, Aníbal Pinto de. Retórica e teorização literária em Portugal: do Humanismo ao Neoclassicismo. 2. ed. Lisboa: Imprensa Nacional-Casa da Moeda, 2008.

CASTRO, A. P. de. Retórica e teorização literária em Portugal: do Humanismo ao Neoclassicismo. Coimbra: CER, 1973.

MENDES, Margarida Vieira. A oratória barroca de Vieira. Lisboa: Editorial Caminho, 1989. $596 \mathrm{p}$.

MENDES, Margarida Vieira. Sermões do padre Antônio Vieira. 3. ed. Lisboa: Comunicação, 1987. $134 \mathrm{p}$.

VIEIRA, Antônio. Sermões: I. Edição Crítica. Lisboa: Imprensa Nacional-Casa da Moeda, 2008. 574 p. 